\title{
Do Advertising Pieces that Portray Brazilian Jeitinho Influence Dishonest Behavior?
}

\author{
Jéssica Farias ${ }^{1}$ \\ Ronaldo Pilati ${ }^{1}$ \\ ${ }^{1}$ University of Brasilia, Brasilia, Distrito Federal, Brasil
}

\begin{abstract}
This research aimed at investigating whether watching Brazilian advertising pieces that portray a sociocultural behavioral pattern called Brazilian jeitinho would influence participant's subsequent behavior. One carried out an experiment in which 200 subjects watched and assessed three advertisement pieces. Upon recruitment, participants were informed that they would be taking part in a raffle for a gift card. The number of tickets received per participant was defined by a die-under-cup task. The more tickets they obtained, the higher the chance to receive the prize, providing an incentive to cheat. Afterwards, respondents took part in a task that defined the number of tickets that each would receive to participate in the raffle. Independent variables consisted in the manipulation of priming of jeitinho (video content: jeitinho or neutral) and privacy of the task (with or without privacy). On the other hand, the dependent variable consisted in the result obtained when participants rolled the dices that defined the number of tickets. One found a significant difference between the groups in which privacy was manipulated, indicating that the groups that performed the task aimed at measuring dishonesty with privacy actually tended to report lower values than the ones actually obtained, entailing an effect of contrast. This finding suggests that the implementation of public policies that utilize propaganda that portrays Brazilian jeitinho could reduce engagement in dishonest behavior among Brazilians.

Keywords: advertising; culture; decision-making; social influence; social norms
\end{abstract}

\section{Peças Publicitárias que Retratam Jeitinho Brasileiro Influenciam o Comportamento Desonesto?}

\section{Resumo}

Esta pesquisa objetivou investigar se assistir a peças publicitárias nacionais representativas de um padrão de comportamento sociocultural do Brasil, o jeitinho brasileiro, influenciaria o comportamento subsequente dos participantes. Realizou-se um experimento no qual 200 participantes assistiram e avaliariam três anúncios publicitários. Ao serem recrutados, os participantes foram informados de que estariam concorrendo a um sorteio de um vale-presente. O número de tickets do sorteio foi definido por uma tarefa que consistiu em jogar um dado dentro de um copo. Quanto mais tickets obtivessem, maior a chance de ganhar o prêmio, criando-se um incentivo para trapacear. As variáveis independentes constituíram a manipulação da pré-ativação (priming) de jeitinho (conteúdo das peças: jeitinho ou neutro) e da privacidade da tarefa (com ou sem privacidade). Já a variável dependente consistiu no resultado obtido ao jogar dados para definir o número de tickets. Encontrou-se diferença significativa entre os grupos para manipulação de privacidade, indicando que os participantes que realizaram a tarefa de mensuração de desonestidade com privacidade tenderam a reportar valores menores do que os que realmente obtiveram no sorteio, ocasionando um efeito de contraste. Esse achado sugere que a implementação de políticas públicas utilizando propagandas que retratem o jeitinho brasileiro podem reduzir o engajamento em comportamento desonesto entre os brasileiros.

Palavras-chave: publicidade, cultura, tomada de decisão, influência social, normas sociais

\section{¿ Los anuncios publicitarios que retratan al jeitinho brasileño influyen en el comportamiento deshonesto?}

\section{Resumen}

Este estudio tuvo como objetivo investigar si ver anuncios publicitarios brasileños que retratan a un patrón de comportamiento sociocultural denominado jeitinho brasileño influiría en el comportamiento posterior de los participantes. Se realizó un experimento donde 200 individuos vieron y evaluaron tres anuncios publicitarios. Al ser reclutados, se les informó a los participantes que se realizaría un sorteo de una tarjeta de regalo. El número de boletos de cada participante fue definido mediante una tarea que consistía en lanzar un dado a una taza. Cuantos más boletos obtuvieron, mayor fue la posibilidad de recibir el premio, lo que ofreció un incentivo para hacer posibles trampas. Posteriormente, los encuestados participaron en una tarea que definió la cantidad de boletos que cada uno recibiría para participar en el sorteo del premio. Las variables independientes consistieron en la manipulación de la preactivación (priming) de jeitinho (contenido de los videos: jeitinho o neutro) y de la privacidad de la tarea (con o sin privacidad). Por otro lado, la variable dependiente consistió en el resultado obtenido cuando los participantes lanzaron los dados que definían el número de boletos. Se encontró una diferencia significativa entre los grupos en los que se manipuló la privacidad, lo que indica que en los grupos que realizaron la tarea dirigida a medir la deshonestidad con privacidad, en realidad tendían a informar valores más bajos que los que realmente obtuvieron, lo que conlleva un efecto de contraste. Este resultado sugiere que la implementación de políticas públicas utilizando propaganda que retrata al jeitinho brasileño podría reducir la participación en conductas deshonestas entre los brasileños.

Palabras clave: publicidad; cultura; toma de decisiones; influencia social; normas sociales 


\section{Introduction}

If, on the on the hand, people enjoy thinking about themselves as honest, on the other hand, dishonesty may be worthwhile in the long term. In the face of this conflict, individuals tend to behave dishonestly enough to obtain benefits, but they do not lie to the maximum extent so not to harm their positive self-image (Mazar, Amir, \& Ariely, 2008; Fischbacher \& Föllmi-Heusi, 2013; Pascual-Ezama et al., 2015), which is in agreement with theory of self-concept maintenance (Mazar et al., 2008). In this vein, individuals tend not to be willing to lie to obtain very small profits (Shalvi et al., 2011), however, at the same time, extremely large incentives may result in less cheating (Hilbig \& Thielmann, 2017). This suggests that higher incentives increase perception of dishonesty, incurring higher psychological costs (Thielmann \& Hilbig, 2019).

Facing an opportunity to benefit from being dishonest may cause a state of mental discomfort generated by a conflict with internal patterns of honesty. This happens when an individual holds two or more beliefs, ideas or values that are contradictory, engaging in a dissonant state described in the scope of cognitive dissonance theory (Festinger, 1962; Harmon-Jones \& Mills, 2019). Mazar, Amir and Ariely (2008) suggest that people typically solve this motivational issue by finding balance between the two motivational forces. A process of convincing oneself that ethical patterns do not apply to a certain context called moral disengagement is then initiated. Thus, an individual persuades himself/ herself that the questionable behavior is allowed (Bandura, 2016).

In the Brazilian context, there is a sociocultural behavioral pattern that is regarded as common and involves violation of social (or legal) norms, creating a trade-off between the individual and bigger social and/ or institutional interests (Miúra et al., 2019). This pattern is known as Brazilian jeitinho and comprises a complex set of features, possibly being assessed as either positive or negative (Miúra et al., 2019). Jeitinho Simpático consists of a positive dimension, which emphasizes creative and affective aspects of this strategy and represents an attempt to solve problems maintaining harmony in relationships in an environment that is excessively formal and bureaucratic (Miúra et al., 2019). Conversely, Jeitinho Malandro is negatively evaluated because it involves disregard for rules and may harm other people due to employing trickery to take advantage of others (Miúra et al., 2019).
Previous research has shown that norm and value internalization patterns were observed in a much subtle extent in children, suggesting that one needs time to learn and progressively internalize moral norms (Glätzle-Rützler \& Lergetporer, 2015). Another variable that influences dishonesty is gender, for women are frequently pointed out as less corrupt than men (Rivas, 2013). As for income, a study has indicated that people with lower income demonstrated a stronger intention of violating norms in a context of uncertainty (Farias \& Pilati, 2020). Therefore, one can expect that individuals with lower income may have a strong incentive to cheat.

This study aims at analyzing the effect of exposition to primes of Brazilian jeitinho on engagement in dishonest behavior. It also aims at investigating the role of socioeconomic variables (age, gender, and income) in this type of behavior.

\section{Individual characteristics and dishonesty}

The factors of Big Five personality inventory consciousness and agreeableness are negatively correlated with dishonesty (Giluk \& Postlethwaite, 2015). Consciousness consists of a personality trait that involves the tendency to control impulses and act in a socially desirable manner. Individuals with high scores are prone to be goal oriented, postpone gratifications, and follow norms and rules (Roberts et al., 2009). On the other hand, agreeableness comprises the personality trait of being concerned with the way individuals approach interpersonal relationships (Giluk \& Postlethwaite, 2015). People who hold high scores are agreeable, affectionate, confident, and concerned about others' wellbeing (Giluk, \& Postlethwaite, 2015), tending to be cooperative and helpful (Graziano \& Tobin, 2009). Both factors are negatively linked to deviant behavior in the workplace (Salgado, 2002) and with antisocial behavior (Miller \& Lynam, 2001). For these reasons, it is unlikely that individuals with high scores in consciousness and agreeableness engage in socially unacceptable behaviors.

Gender also consists of a variable that influences dishonesty. Women are found to be less corrupt than men (Rivas, 2013), for, overall, they are less prone to sacrifice the common good to obtain private gain (Dollar et al., 2001). In fact, one discovered that the larger the representation of women in Parliament, the lower are corruption levels (Dollar et al., 2001). However, another possible explanation is that women would tend to be more prone to respond in a socially desirable manner (Dalton \& Ortegren, 2011), denying 
having engaged in dishonest behavior more than men do (Witme \& Johansson, 2015). Women also tend to have higher scores in agreeableness whereas men score higher in dominance - which is positively correlated with competitiveness (Biron, De Reuver, \& Toker, 2016). This could explain the link between gender and dishonesty.

Nonetheless, competitiveness - an aspect of male role norms - is pointed as a factor that is more determinant of dishonest behavior than gender itself (Zhang \& Yin, 2018). Magian and Montinari (2017) found that, in the workplace, women who are more competitive and have higher performance are even more dishonest than male colleagues with the same levels of competitiveness and performance. In an experiment, one found that parents act more honestly under the scrutiny of daughters in comparison with sons (Houser et al., 2016). This result may indicate the origin of gender differences that are widely reported in cheating behavior among adults, in which a typical behavior is that women are more honest than men.

Dishonesty tends to decrease as one gets older. Glätzle-Rützler and Lergetporer (2015) reported that the frequency of lies diminished significantly with age (a group aged 10 to 11 years old in comparison with another group aged 16 to 17 years old), despite the fact that a significant number of individuals of both age brackets showed aversion to lies. In fact, as children grow up, they become increasingly more concerned about looking fair to others, which could explain part of their increasing trend to behave in a fair manner (Shaw et al., 2014). Fosgaard (2020) suggests that dishonesty is linked to an inverse mechanism that is U-shaped, increasing from childhood until reaching the peak in adolescence and decreasing until reaching elderhood. This trend follows the crime-age curve closely (Hirschi \& Gottfredson, 1983; Farrington, 1986), which consists of a curvature that is applied to a wide range of criminal activities. This suggests that the relationship between bad conduct and age has a wider scope of applicability and also translates into dishonesty in regular people (Fosgaard, 2020).

Brazil is a country with high income inequality. In the year of 2018 , the $1 \%$ richest earned 34 times more than the half poorest. In the same year, 10.4 million Brazilians (5\% of the country' population) earned $\mathrm{R} \$ 51$ per month (equivalent to U\$ 9.28), and 104 million Brazilians earned up to $\mathrm{R} \$ 413$ (equivalent to US $\$ 75.12$, about $36 \%$ of the current minimal wage of $\mathrm{R}$ $\$ 1,145$ ) (IBGE, 2020). In this regard, Farias and Pilati
(2020) found that income may influence engagement in antinormative behavior. For instance, Brazilians with high lower income demonstrated stronger predisposition towards violating social distancing rules during the COVID-19 pandemic (Farias \& Pilati, 2020). In a similar vein, individuals with lower income may have a strong incentive for cheating and obtaining financial gains.

\section{Brazilian jeitinho and social norms}

Engaging in antinormative behaviors depends, to a certain extent, on how prevalent is norm violation in the society where someone lives (Keizer, Lindenberg, \& Steg, 2008). From a social learning standpoint, it is more likely that individuals perform an immoral behavior if it is accepted or promoted by relevant others such as parents and friends (Kam, Hue \& Cheung, 2018). Therefore, if cheating is profoundly embedded in a society and goes unpunished, people may start to see daily dishonesty as justifiable, not compromising their self-concept of dishonesty any longer (Gino, Ayal, \& Ariely, 2009).

Engaging in strategies such as self-serving justifications (Shalvi et al., 2015) is relevant to individuals because, if one does now comply with one's internal patterns of honesty, it is necessary to negatively update one's self-concept, which is aversive. Dishonesty increases in the face of such justifications, whether they occur before or after moral violation (Shalvi et al., 2015). This happens because these justifications diminish threats to the moral self, allowing individuals to commit mistakes while feeling moral (Shalvi et al., 2015).

Norms consist of a particularly relevant predictor of behavior in Brazil, for there is emphasis in values of conservation - conformity and safety (Torres, Porto, \& Fischer, 2015). In the Brazilian context, Brazilian jeitinho comprises a cultural phenomenon that is characterized by notions of creativity and simpatia (affective and prosocial orientation) - Jeitinho Simpático dimension - as well as norm violation and corruption - Jeitinho Malandro dimension (Miúra et al., 2019). In its most typical form, jeitinho involves violation of social (or legal) norms. This form of jeitinho stems from the need to break norms amid severe social restrictions in order to meet personal goals, creating a trade-off between the individual and social and/or bigger institutional interests (Miúra et al., 2019).

Considering that violation of social and legal norms tends to be negatively assessed, many Brazilians 
consider jeitinho as a detrimental practice (Miúra et al., 2019). However, most individuals recognize it as a valid problem-solving strategy because it is effective and therefore it becomes acceptable (Pilati et al., 2011). One argues that the main issue regarding jeitinho consists of the dissemination of the generalized perception of Brazil in a negative way, as if corruption and illegality were part of Brazilians' cultural heritage and essence (Wachelke \& Prado, 2017). On the other hand, this mechanism comprises an individualistic strategy that leads Brazilians to disregard the attack on jeitinho and its contradictions, which results in reproducing it indefinitely.

Brazilian jeitinho is related to a conflict between injunctive norms - perceptions on what is approved or disapproved by others (Cialdini, Reno, \& Kallgren, 1990) - and descriptive norms - perceptions of how people actually behave (Cialdini et al., 1990). Despite injunctive norms on jeitinho generally reflect disapproval, it is possible that Brazilians have expectations that their compatriots behave in consonance with jeitinho due to its efficiency. In this regard, when individuals engage in jeitinho, they strategically avoid some negative reactions of norm violation by employing social influence techniques that soften and reestablish interrupted social relationships by using simpatia (Pilati et al., 2011).

\section{Priming of Brazilian jeitinho}

When it comes to the literature on Brazilian jeitinho, one can notice that there is lack of studies regarding the identification of typical behaviors with the aim of selecting stimuli to be used as primes in experiments. Priming is defined as the process through which recent sensorial experiences create perceptual and behavioral prompts in an automatic way (Bargh \& Chartrand, 2014). When employing the priming procedure, participants are exposed to stimuli in either a conscious or a preconscious level, which make certain perceptual categories more accessible to the working memory and may elicit subsequent perceptual and behavioral trends related to this stimulus (Rabelo, Hees, \& Pilati, 2012).

Stimuli have a powerful influence on judgement and decision-making, being able to cause effects of either assimilation or contrast. When assimilation occurs, the introduction of an anchor influences judgement towards the positive direction (Bless \& Burger, 2016). On the other hand, when contrast happens, the judgement of a certain target stimulus is inversely related to the values that accompany it.
Employment of primes is in agreement with recent advances in social cognition theorization, taking dual processing models into consideration (Kahneman, 2011). These models, in turn, appraise the existence of opposing and interchangeable systems of information processing. Among other forms, stimuli are presented by scenarios (Motro, Ordóñez, Pittarello, \& Welsh, 2016), images or videos (Givens \& Monahan, 2009).

A variety of studies has already used advertising pieces as primes, whose content has influenced subsequent automatic behaviors such as stronger ethical awareness (Smith \& Weinberg, 2016), improved perception and content recognition of advertising pieces (Wu et al., 2016), and impact on participants' humor (Yoon \& Lee, 2019). Considering that Brazilian jeitinho consists of a cultural phenomenon that is typical of the Brazilian culture, it is expected that national advertising pieces portray this social navigation mechanism. Exposition to different types of content may activate the most accessible contents on individuals' memories and may influence attitudes and subsequent actions. Therefore, it is relevant to analyze whether advertising pieces that portray Brazilian jeitinho influence individuals towards engaging in more (assimilation effect) or less jeitinho (contrast effect). Seeing that this social navigation mechanism has a dimension of Jeitinho Malandro, which involves social norms violation, if assimilation occurs, exposition to this sort of content may affect engagement in dishonest behavior.

In this research, we use three advertising pieces that portray Brazilian jeitinho. These pieces were selected in a previous study that aimed at choosing stimuli to be used as primes of jeitinho (Farias, 2018). We expect that, once participants watch the advertising pieces, the priming of jeitinho will convey the descriptive norm of "taking advantage" salient and that this will influence participants' decision-making towards behaving dishonestly in a subsequent task. Other three neutral advertising pieces were selected to be applied in the control group. In this study, we expect that participants in the experimental group assimilate the priming of Brazilian jeitinho. Considering the Jeitinho Malandro dimension that is associated to it, we expect that participants exposed to the priming of jeitinho will cheat more in the task aimed at assessing dishonest behavior. That is, we expect that there will be an assimilation effect of the priming. This assimilation is expected because we assume that the priming will remind participants that taking advantage is common in the context they are embedded. 
This research aims at finding evidence of the applicability of the theory of self-concept maintenance (Mazar, Amir, \& Ariely, 2008) in the Brazilian context. Seeing that most allegations on human psychology are based on samples taken from western, educated, industrialized, rich, and democratic societies (WEIRD) (Henrich, Heine, \& Norenzayan, 2010), it is necessary to verify whether the findings and theories applied to WEIRD societies are also applicable to non-WEIRD ones. In this regard, we present two hypotheses:

Hypothesis 1: Participants primed with Brazilian jeitinho stimulus will cheat more if compared to participants primed with neutral stimulus.

Hypothesis 2: Participants who perform the task aimed at measuring dishonest behavior with privacy will cheat moderately, so that they are able to maintain a positive self-concept, if compared with participants in the control group.

\section{Method}

\section{Participants}

The sample was obtained through convenience sampling and was composed of 200 participants (125 women, 75 men, mean age $=20.92$, SD $=4.56)$ uniformly distributed between the experimental conditions. We used the software G*Power to perform the sample size calculation. For doing so, we considered the performance of a factorial ANOVA with type I error (0.05), power of the test (0.80), medium effect size $(0.20)$, and number of groups (4). However, one decided to collect more cases to account for the possibility of a smaller effect size than estimated. The sample was composed of students in University of Brasilia (UnB), in the Federal District.

\section{Measures and materials}

Advertising pieces. Three advertising pieces of two different brands were selected to be applied to the Brazilian jeitinho group: Itaipava and Havaianas. These pieces were selected in a previous study (Farias, 2018) in which participants evaluated seven advertising pieces that were presented in a standardized way. The three pieces that obtained the highest score in Jeitinho Malandro were selected. These pieces presented a story with one or more main characters and had the duration of approximately 30 seconds each. The ones presented to the experimental group were: Swear Words (Itaipava), Salesman (Havaianas), and Street Vendor (Havaianas) - Three other videos were applied to the control group: Powerful Liquidation (Casas Bahia), Super Sale (Ricardo Eletro), and Red Friday Promotions (Lojas Americanas). These latter pieces do not portray social interaction, only promoting products.

Attitudes towards advertising pieces scale (ATAPS). It consists of a differential semantic scale that was developed by Madden, Allen and Twible (1988), in which individuals ought to evaluate whether the pieces can be described by eight pairs of adjectives. The pairs used were: vulgar/refined, pleasant/unpleasant, likeable/unlikeable, interesting/boring, tasteful/ tasteless, entertaining/unentertaining, artful/artless, familiar/novel, good/bad, and insulting/uninsulting. Participants evaluated these pairs in a five-point scale (for example, 1-Totally vulgar, 5-Totally refined). Three questions were answered after each ad: "What is the brand promoted?", "what is the video's topic?", and "what are the products promoted?". This measure was not analyzed, only consisting of a mechanism to lead participants to watch the ads with attention so that the priming of jeitinho could work properly.

Personal Jeitinho Scale (PJS). The shortened version of PJS was used in this research. It is composed of 18 items and presents two dimensions: Jeitinho Simpático and Jeitinho Malandro. It presents affirmations that portray people in certain circumstances. To answer the scale, participants must read each description and evaluate how much each person is similar to him or her. An example of item is as follows: "He likes to maintain a pleasant social climate". The scale was scored at six points (1- He sounds nothing like me to $6-\mathrm{He}$ sounds very much like me). Cronbach's alpha was 0.75 for Jeitinho Simpático and 0.77 for Jeitinho Malandro (Miura et al, 2019).

Sociodemographic measure (SM). The following information was collected: gender, educational level, age, and income. Gender was measured in a binary form (0- Woman, 1- Man). The educational level was measured at four points (1-Completed elementary school, 2- Completed high school, 3- Undergraduate degree, 4- Post-graduation). Age was requested through the open question "what is your age?". It ranged from 18 to 54 years old. Income was reported through a scale scored at nine points, ranging from "up to one minimal wage" to "above 15 minimal wages" (1- Up to R \$ 937.00 to 9 - Above $\mathrm{R} \$ 14,055.01)$.

Dice. To perform the task aimed at assessing dishonest behavior, we used the die-under-cup paradigm. Participants performed the task by rolling a die under a cup, and the number obtained $(0,1,2,3,4$, 
or 5) defined the number of tickets to participate in a raffle for a gift card.

\section{Procedure}

The research involved a 2 (privacy: with or without) $\mathrm{x} 2$ (priming: jeitinho or neutral) design. Each participant's condition was previously defined randomly. We used a website (www.randomization.org) to randomize the conditions' distributions so that there would be approximately 50 participants per condition.

Data collection occurred presentially. Participants were informed that they would be taking part in a study on consumer psychology in which they were supposed to evaluate advertising pieces. Participants were then taken to one laboratory room. They were told that, by taking part in the study, they were automatically eligible to a raffle for a gift-card worth $\mathrm{R} \$ 130.00$ in a national chain bookstore.

Firstly, participants were primed according to the group they were allocated (priming: jeitinho or neutral). Then they assessed the three ads by answering ATAPS. This scale was only applied to have a plausible reason to explain to participants why they should watch the advertising pieces and therefore mobilize their attention to the ads' content so that one could optimize the effectiveness of the priming of Brazilian jeitinho.

After that, the die-under-cup task was performed. It defined the number of tickets that each participant received to participate in the raffle for the gift card. The raffle was carried out either with or without privacy, depending on the group to which the participant was allocated. In the task, each participant rolled a regular die of six faces, and the number on the upper face defined the number of tickets to participate in the raffle. Therefore, the higher the number of tickets, the more chances participants had to win the raffle. One exception consisted of number six, for we assigned that it corresponded to zero. That is, if the participant obtained six in the die, he or she would not receive any ticket. This task was based on the procedure reported by Fischbacher and Follmi-Heusi (2013).

After the procedure to define the number of tickets in the raffle, participants responded to PJS and to SM. At the end, there was a debriefing, in which participants were told the purpose of the study. To have a clearer understanding of the procedure, see Figure 1.

Ethics statement. This study strictly followed the Ethical Principles in the Conduct of Research with Human Participants proposed by the American Psychological Association. Participants were informed about the research purpose, the risks involved in taking part of the research, and the confidentiality and anonymity of the participation. Participants explicitly informed their consent in taking part of the research by checking a box and were free to quit their participation at any moment. No personal information was collected to preserve participants' anonymity.

\section{Results}

This research's independent variables (IVs) consist of the manipulation of priming (Brazilian jeitinho or neutral) and privacy (with or without it). The dependent variable (DV), on the other hand, consists of the number obtained when performing the die-under-cup task. Firstly, one performed descriptive analyses to assess whether the assumption of the DV's normality was met. Considering that the DV was found to be non-parametric, one decided to perform a rank transformation in the univariate analyses. This type of transformation is useful in hypotheses testing in experimental designs (Iman \& Conover, 1979). Besides, ranking the DV comprises a method that works really well for regression analyses in monotonic data.

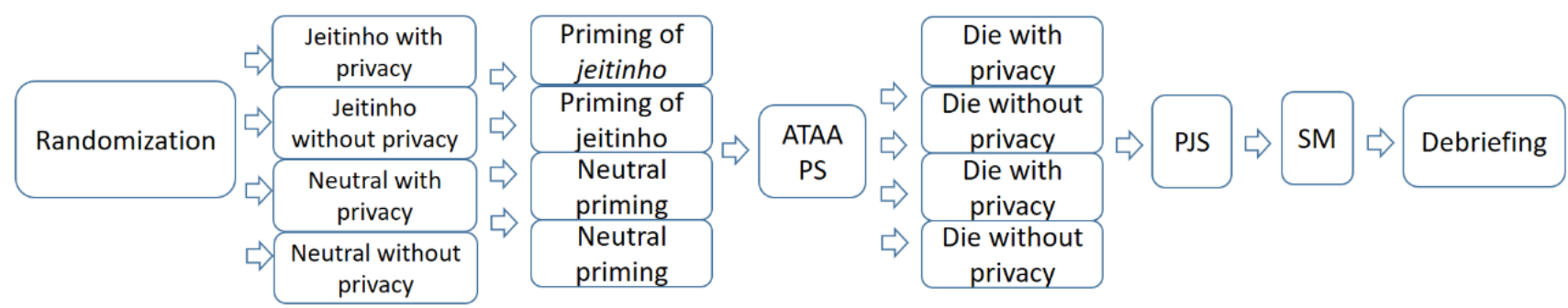

Figure 1. Schematized procedure of the study. 
The analysis revealed that there was not a significant effect either for the manipulation of privacy, $\mathrm{F}$ (1, 196) $=0.235, \mathrm{p}=.628, \eta^{2} \mathrm{p}=.001$, or for the interaction between manipulation of priming and privacy, $\mathrm{F}$ $(1,116)=0.487, p=0.49, \eta^{2} p=0.0002$. Nevertheless, there was a marginally significant effect for the manipulation of the videos' content, $\mathrm{F}(1,196)=2.91$, $\mathrm{p}=0.09, \eta^{2} \mathrm{p}=0.015$. The group that watched neutral videos $(\mathrm{M}=2.89, \mathrm{EP}=0.17)$ reported higher numbers when compared to the one that watched videos of Brazilian jeitinho $(\mathrm{M}=2.48, \mathrm{EP}=0.17)$. This difference can be seen more clearly in Figure 2.

From the data in Table 1, it is possible to compute the percentage of income maximizers (Fischbacher \& Follmi-Heusi, 2013), that is, the percentage of individuals who lie to obtain the maximum reward and therefore have a higher chance of winning the raffle. For the income maximizers' group, the average score should equal five. Considering that each of the six faces has the same probability of being obtained, if participants are honest, each face must have a frequency of $16.67 \%$. In this research, this percentage was $3.36 \%$, being obtained through the following calculation: $(19,5 \%-16,7 \%) * 6 / 5$. On the other hand, the group whose mean score equals four consists of the "partial liars". Finally, a group whose informed mean result does not exceed the expected result in a fair die-rolling is classified as honest.

By analyzing the frequency of participants who obtained zero (15\%) and, assuming that everyone

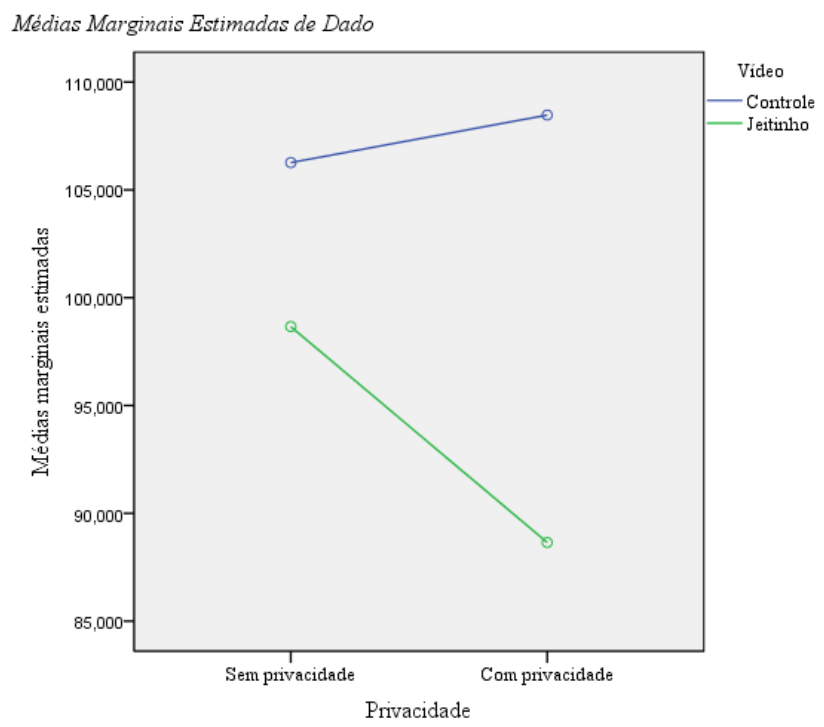

Figure 2. Ranked scores of die-under-cup task who reported this number was honest, one can infer the total percentage of participants who was honest by multiplying this number per six. This total equals $90 \%$. The most consistently reported numbers (3, 4, and 5) presented a higher percentage than the lower numbers $(0,1$, and 2$)$. By considering the information in Table 2, one can compare the frequencies reported by the group that was primed with Brazilian jeitinho and neutral stimuli, respectively. The faces with higher numbers were reported systematically more frequently in the neutral group, if compared to the group that watched advertising pieces about jeitinho, in which an opposite trend was observed.

The variable income, $\mathrm{t}=-1.84, \mathrm{~B}=-.09, \mathrm{p}=.07$, $\mathrm{R}^{2}=.017$, was a marginally significant predictor of the numbers obtained in the die-under-cup task. A weak correlation of gender, $\mathrm{r}=-.17, \mathrm{p}=.018$, and age, $\mathrm{r}=.15$, $\mathrm{p}=.04$, with Jeitinho Simpático was found.

\section{Discussion}

This study aimed at identifying whether exposing individuals to advertising pieces that contain Brazilian jeitinho would influence engagement in dishonest behavior as well as whether performing the task aimed at measuring dishonesty with or without privacy would influence the participants' behavior. Hypothesis 1 states that there would be more cheating in the group exposed to jeitinho stimulus due to an assimilation effect of priming, and it was refuted. This result contradicts the ones reported by Mazar, Amir, and Ariely (2008), Fischbacher and Föllmi-Heusi (2013), and Pascual-Ezama et al. (2015), indicating that participants tend to cheat to a low extent, so that they can maintain their self-concept of honesty. Thus, the effect of priming of advertising pieces was of contrast and not of assimilation in the realm of this research.

When it comes to contrast, one of the reasons for finding this type of effect lies in lack of ambiguity of the stimulus. Her (1986) found contrast effects when extreme categories of priming were presented and effects of marginal assimilation when moderate categories were presented. These effects of contrast and assimilation held even stronger when participants evaluated negative features, however contrast occurred for positive judgements. In the scope of this research, one of the possible reasons for obtaining effects of contrast may lie in the extreme and nonambiguous character of the stimuli presented in the advertising pieces. 
Table 1.

Frequency and percentage of the numbers obtained in the die-under-cup task.

\begin{tabular}{ccccc}
\hline Die & Frequency & Percentage & Valid percentage & Cumulative percentage \\
\hline 0 & 30 & 15.0 & 15.0 & 15.0 \\
1 & 27 & 13.5 & 13.5 & 28.5 \\
2 & 30 & 15.0 & 15.0 & 43.5 \\
3 & 41 & 20.5 & 20.5 & 64.0 \\
4 & 33 & 16.5 & 16.5 & 80.5 \\
5 & 39 & 19.5 & 19.5 & 100.0 \\
Total & 200 & 100.0 & 100.0 & \\
\hline
\end{tabular}

Table 2.

Distribution of the numbers obtained in the die-under-cup task for neutral and jeitinho priming groups

\begin{tabular}{cccc}
\hline \multicolumn{2}{c}{ Neutral priming } & \multicolumn{2}{c}{ Jeitinho priming } \\
\hline Die & Frequency & Die & Frequency \\
\hline 0 & 12 & 0 & 18 \\
1 & 12 & 1 & 15 \\
2 & 15 & 2 & 15 \\
3 & 20 & 3 & 21 \\
4 & 18 & 4 & 15 \\
5 & 23 & 5 & 16 \\
Total & 100 & Total & 100 \\
\hline
\end{tabular}

One refuted Hypothesis 2, which stated that participants that performed the task aimed at measuring dishonest behavior with privacy would tend to cheat moderately more than the group that performed it without privacy so that their positive self-concept be maintained. Actually, there was not a significant difference between the groups. In this study, instead of eliciting dishonest behavior, privacy seemed to increase the consciousness relative to patterns of honesty, contradicting the reports Mazar, Amir, and Ariely (2008), Fischbacher and Föllmi-Heusi (2013), and Pascual-Ezama et al. (2015). Data obtained from participants' debriefing as well as the experience obtained through performing another experimental study on dishonest behavior (Farias, 2018) point out that participants of studies conducted in laboratories tend to believe that they are being monitored. Reporting lower numbers may have been the manner that participants found to reaffirm their self-concept of honesty.
Income worked as a predictor of the task aimed at assessing dishonest behavior, indicating that, the lower the income, the more engagement in dishonesty. This finding meets the report that Brazilians with lower income violate rules due to financial reasons (Farias \& Pilati, 2020). One believes that this result is explained by the fact that individuals with lower income may have a stronger incentive to cheat and obtain financial gains so that they meet their needs, especially in a country with high income inequality such as Brazil. Besides, Farias and Pilati (2020) found that professional stability was another factor that influenced the intention of violating norms. One found a weak correlation between gender and Jeitinho Simpático, indicating that women tend to engage more in this dimension of jeitinho, which can be explained by the fact they tend to present high scores in agreeability (Biron, De Reuver, \& Toker, 2016). Engagement increased with age, which contradicts the report of Glätzle-Rützler and Lergetporer (2015). That is, participants tended to cheat more as they got older. 
The studies in which this research was based upon - such as the ones by Mazar, Amir, and Ariely (2008), Gino, Ayal, and Ariely (2009), Fischbacher and Föllmi-Heusi (2013), and Pascual-Ezama et al. (2015) - present claims about human psychology that entirely rely on samples collected from western, educated, industrial, rich, and democratic societies (WEIRD). In these studies, one assumes that there is little variation among human populations or that their subjects are as representative of the species as any other population. However, members of WEIRD societies are among the least representative people that one can find to generalize discoveries about human beings (Henrich, Heine, \& Norenzayan, 2010). Therefore, one of the possible reasons for the discrepancy in the results may lie in cultural factors that exist in the population from which the samples were taken in the studies used as reference (WEIRD) and the sample used to perform this study (non-WEIRD).

The fact that this research's sample was exclusively composed of university students concentrated in just one of the federal units of Brazil may also have biased the results. In this vein, the classic work of Sears (1986) warned about the dangers of making wide generalizations about the nature of human psychology based in such limited samples, for, in comparison with older adults, university students present less crystalized attitudes, a less formulated sense of self, stronger trends to obey authority, and less stable group relationships. Approximately 20 years later, Henry (2008) pointed that a large share of the current research is still based on samples composed of students, which influence the conclusions which science relies on.

It is necessary that studies with more diversified samples be performed so that they do not incur such bias. One suggests the performance of field experiments, a methodology that involves experimental interventions in real-world scenarios, outside university environment. It is also possible to perform online experiments, with a diversified sample. Besides, to confirm if the reported findings are consistent and reliable, it is necessary to perform replication studies as well as cross-cultural studies on the processes analyzed in this research.

It is possible that participants did not behavior the way they would if they came across the opportunity to be dishonest in their daily lives because they were in a laboratory environment, which is different from their daily reality (Berkowitz \& Donnerstein, 1982; Mook, 1983). Future research is advised to explore the performance of experiments with stronger psychological realism, simulating daily reality in a more plausible way. Observational studies are also highly suggested to achieve more external validity. For instance, one may observe participants' behavior when finding an object purposely left outside the laboratory, just after participants were primed so that the priming effect could be observed in a more reliable way.

Another caveat is that some factors such as selfesteem and conformity to social norms, which possibly interfered in the results, were not either measured or manipulated. Finally, another point to be questioned is whether the incentive used in this study - the quantity of tickets to participate in the raffle for the $\mathrm{R} \$ 130$ gift card to be spent in a bookstore — was a strong incentive enough to compel participants to cheat. One suggests that future research on dishonest behavior use more tangible incentives that involve the certainty of obtaining an immediate reward, so that participants become more engaged in the task. The reward could consist of some type of compensation that resulted from the performance of the task aimed at measuring dishonest behavior. The compensation should be delivered as the research was carried out in such a way that the benefit would not be something as uncertain as the result of a raffle but a granted compensation.

This research presented the proposition of using advertising pieces portraying Brazilian jeitinho as stimuli in priming procedures as its main contribution. It was found that exposition to Brazilian jeitinho content caused a contrast effect, not an assimilation one, as it was expected. Therefore, instead of having participants engaging in more dishonest behavior due to the exposition to stimuli of Jeitinho Malandro, they engaged less in such type of behavior, being more honest. One expects that this research incentives the performance of experimental studies and field studies on Brazilian jeitinho using a similar type of paradigm to verify whether these results will stand. Furthermore, this finding may work as a theoretical basis to the elaboration of public policies that propose using propaganda that portray Brazilian jeitinho to reduce engagement in dishonest behavior among Brazilians.

\section{References}

Bandura, A. (2016). Moral disengagement: How people do harm and live with themselves. Worth Publishers.

Bargh, J. A., \& Chartrand, T. L. (2014). The mind in the middle: A practical guide to priming and 
automaticity research. Em H. T. Reis \& C. M. Judd (Eds.), Handbook of research methods in social and personality psychology. Cambridge University Press.

Biron, M., De Reuver, R. \& Toker, S. (2016). All employees are equal, but some are more equal than others: dominance, agreeableness, and status inconsistency among men and women. European Journal of Work and Organizational Psychology, 25(3), 430-446. doi: 10.1080/1359432X.2015.1111338

Bless, H., \& Burger, A. M. (2016). Assimilation and contrast in social priming, Current Opinion in Psychology, 12, 26-31. doi: 10.1016/j.copsyc.2016.04.018.

Cialdini, R. B., Reno, R. R., \& Kallgren, C. A. (1990). A focus theory of normative conduct: Recycling the concept of norms to reduce littering in public places. Journal of Personality and Social Psychology, 58, 1015-1026. doi: 10.1037/0022-3514.58.6.1015

Dalton, D., \& Ortegren, M. (2011). Demonstrating an Illusory Preference for Fairness. Journal of Business Ethics, 103,73-93. doi: 10.1007/s10551-011-0843-8

De Neys, W., \& Pennycook, G. (2019). Logic, Fast and Slow: Advances in Dual-Process Theorizing. Current Directions in Psychological Science, 28(5), 503-509. doi: 10.1177/0963721419855658

Dollar, D., Fisman, R., \& Gatti, R. (2001). Are women really the "fairer" sex? Corruption and women in government. Jour. of Econ. Behav. \& Organ., 46(4), 423-429. doi: 10.1016/S0167-2681(01)00169-X

Farias, J. (2018). Influência da manipulação de jeitinho e de privacidade no engajamento em comportamento desonesto. Dissertação de mestrado. Retrieved from: repositorio.unb.br/handle/10482/31893

Farias, J. \& Pilati, R. (2020). Violating social distancing amid COVID-19 pandemic: Psychological factors to improve compliance. PsyArXiv. doi: 10.31234/ osf.io/apg9e

Festinger, L. (1962). Cognitive Dissonance. Scientific American, 207(4), 93-106. Retrieved from: http:// www.jstor.org/stable/24936719

Fischbacher, U., \& Follmi-Heusi, F. (2013). Lies in disguise - An experimental study on cheating. Journal of the European Economic Association, 11(3), 525-547. doi: $10.1111 /$ jeea.12014

Fosgaard, T.R. (2020). Students Cheat More: Comparing the Dishonesty of a Student Sample and a
Representative Sample in the Laboratory. Scand. J. of Economics, 122, 257-279. doi: 10.1111/sjoe.12326

Giluk, T. L., \& Postlethwaite, B. E. (2015). Big five personality and academic dishonesty: A meta-analytic review. Personality and Individual Differences, 72, 5967. doi: 10.1016/j.paid.2014.08.027

Gino, F., Ayal, S. \& Ariely, D. (2009). Contagion and differentiation in unethical behavior: the effect of one bad apple on the barrel. Psychol. Sci., 20, 393398. doi: $10.1111 /$ j.1467-9280.2009.02306.x

Givens, S. M. B., \&Monahan, J. L. (2009). Priming Mammies, Jezebels, and Other Controlling Images: An Examination of the Influence of Mediated Stereotypes on Perceptions of an African American Woman. Media Psychology, 7, 87-106. doi: 10.1207/ S1532785XMEP0701_5

Glätzle-Rützler, D., \& Lergetporer, P. (2015). Lying and age: An experimental study. Journal of Economic Psychology, 46, 12-25. doi: 10.1016/j.joep.2014.11.002

Graziano, W. G., \& Tobin, R. M. (2009). Agreeableness. In M. R. Leary \& R. H. Hoyle (Eds.), Handbook of individual differences in social behavior, 6-61. The Guilford Press.

Harmon-Jones, E., \& Mills, J. (2019). An introduction to cognitive dissonance theory and an overview of current perspectives on the theory. Em E. Harmon-Jones (Ed.), Cognitive dissonance: Reexamining a pivotal theory in psychology. American Psychological Association. doi: 10.1037/0000135-001

Henrich, Heine, \& Norenzayan. (2010). The weirdest people in the world? Behav Brain Sci. 33(2-3), 61-83. doi: 10.1017/S0140525X0999152X.

Hilbig, B. \& Thielmann, I. (2017). Does everyone have a price? On the role of payoff magnitude for ethical decision making. Cog., 163, 15-25.

Houser, D., List, J. A., Piovesan, M., Samek, A., \& Winter, J. (2016). Dishonesty: From parents to children. European Economic Review, 82, 242-254

IBGE (Brazilian Institute of Geography and Statistics). (2020a, April 29). Main Results (October 2018). https://www.ibge.gov.br/en/statistics/ social/population/16833-monthly-disseminationpnadc1.html?edicao $=26129 \& \mathrm{t}=$ destaques

Iman, R. L., \& Conover, W. J., (1979). The use of rank transform in regression. Technometrics, 21(4), 499509. doi: 10.1080/00401706.1979.10489820 
Kahneman, D. (2011). Thinking, fast and slow. Farrar, Straus and Giroux.

Kam, C. C. S., Hue, M. T., \& Cheung, H. Y. (2018). Academic dishonesty among Hong Kong secondary school students: application of theory of planned behavior. Educational Psychology, 38(7).

Keizer, K., Lindenberg, S., \& Steg, L. (2008). The spreading of disorder. Science, 322, 1681-1685. doi: 10.1126/science. 1161405

Madden, T. J., Allen, C. T., \& Twible, J. L. (1988). Attitude toward the Ad: An Assessment of Diverse Measurement Indices under Different Processing "Sets." Journal of Marketing Research, 25(3), 242-252. doi: $10.1177 / 002224378802500302$

Maggian, V., \& Montinari, N. (2017). The spillover effects of gender quotas on dishonesty. Economics Letters, 159, 33-36. doi:10.1016/j.econlet.2017.06.045.

Mazar, N., Amir, O., \& Ariely, D. (2008). The dishonesty of honest people: A theory of self-concept maintenance. Journal of marketing research, 45(6), 633-644. doi: 10.1509/jmkr.45.6.633

Miller, J.D. \& Lynam, D. (2001). Structural models of personality and their relation to antisocial behavior: A meta-analytic review. Criminology, 39, 765-798. doi: 10.1111/j.1745-9125.2001.tb00940.x

Miura, M. A., Pilati, R., Milfont, T. L., Ferreira M. C., \& Fischer, R. (2019). Between simpatia and malandragem: Brazilian jeitinho as an individual difference variable. PLoS ONE, 14(4): e0214929. doi: 10.1371/journal.pone.0214929

Motro, D., Ordóñez, L. D., Pittarello, A., \& Welsh, D. T. (2016). Investigating the Effects of Anger and Guilt on Unethical Behavior: A Dual-Process Approach. Journal of Business Ethics. doi: 10.1007/ s10551-016-3337-x

Pascual-Ezama, D., Fosgaard, T. R., Cárdenas, J. C., Kujal, P., Veszteg, R., De Liaño, B. G. G, Gunia, B., Weichselbaumer, D., Hilken, K., Antinyan, A., Delnoij, J., Proestakis, A., Tira, M. D., Pratomo, Y.; Jaber López, T., Brañas Garza, P. (2015). Contextdependent cheating: Experimental evidence from 16 countries. Journal of Economic Behavior \& Organization, 116, 379-386.

Pilati, R., Milfont, T., Ferreira, M., Porto, J., \& Fischer, R. (2011). Brazilian jeitinho: Understanding and explaining an indigenous psychological construct.
Interamerican Journal of Psychology, 45(1), 29-38. doi: 2013-27873-004

Rabelo, A. L. A., Hees, M. A. G., \& Pilati, R. (2012). A Moderação da Prosocialidade entre o Priming e a Intenção de Gentileza. PSICO, 43(2), 163-173. doi: 2013-13586-004

Roberts, B. W., Jackson, J.J., Fayard, J.V., \& Edmonds, G.W., \& Meints, J. (2009). Conscientiousness. Em Leary, M. R., Hoyle, R. H. (Eds.), Handbook of individual differences in social behavior. Guilford Press, 369-381.

Rivas, M. F. (2013). An experiment on corruption and gender. Bul. of Econ. Research, 65,10-42. doi: 10.1111/j.1467-8586.2012.00450.x

Sears, D. (1986). College Sophomores in the Laboratory: Influences of a Narrow Data Base on Social Psychology's View of Human Nature. J. of Pers. and S. Psyc., 51(3), 515-530. doi: 0022-3514/86/S00.75

Shalvi, S., Dana, J., Handgraaf, M. J. J., \& De Dreu, C. K. W. (2011). Justified ethicality: Observing desired counterfactuals modifies ethical perceptions and behaviour. Organizational Behavior and Human Decision Processes, 115(2), 181-190.

Shalvi, S., Gino, F., Barkan, R., \& Ayal, S. (2015). SelfServing Justifications: Doing Wrong and Feeling Moral. Cur. Direct. in Psych. Sci., 24(2), 125-130. doi: 10.1177/0963721414553264

Smith, J. F. H., \& Weinberg, N. (2016). The Elevator Effect: Advertising, Priming, and the Rise of Cherie Berry. American Politics Research, 44(3), 496-522. https://doi.org/10.1177/1532673X15602755

Thielmann, I., Hilbig, B. E. (2019). No gain without pain: The psychological costs of dishonesty. J. of Econ. Psych., 71, 126-137. doi: 10.1016/j.joep.2018.06.001

Torres, C. V.; Porto, J. B.; Vargas, L. M., Fischer, R. (2015). A meta-analysis of basic human values in Brazil: observed differences within the country. Rev. Psicol., Organ. Trab., 15(1), 89-102. doi: 10.17652/rpot/2015.1.356

Wachelke, J., \& Prado, A. M. (2017). A ideologia do jeitinho brasileiro. Psicologia e Saber Social, 6(2), 146162. doi: 10.12957/psi.saber.soc.2017.31400.

Witme, H., \& Johansson, J. (2015). Disciplinary action for academic dishonesty: does the student's gender matter? International Journal for Educational Integrity, 11(6). doi: 10.1007/s40979-015-0006-2 
Wu, M., Huang, Y., Li, R., Bortree, D. S., Yang, F., Xiao, A., \& Wang, R. (2016). A Tale of Two Sources in Native Advertising: Examining the Effects of Source Credibility and Priming on Content, Organizations, and Media Evaluations. Amer. Behav. Scientist, 60(12), 1492-1509. doi: 10.1177/0002764216660139

Yoon, H. J., \& Lee, Y. (2019). Gender differences in arousal priming effects on humor advertising.
International Journal of Advertising, 38(3), 383-404. doi: 10.1080/02650487.2018.1500243

Zhang, Y., Yin, H. (2018). Investigating academic dishonesty among Chinese undergraduate students: does gender matter? Assess. \& Ev. in Higher Education, 43(5). doi: 10.1080/02602938.2017.1411467

Recebido em: 09/10/2019

Reformulado em: 11/05/2020

Aprovado em: 29/06/2020

About the authors:

Jéssica Farias is a Ph.D candidate and master in Social, Work and Organizational Psychology at University of Brasília (UnB). Her research interests include experimental social psychology, social cognition, cross-cultural psychology and data analysis. She currently researches dishonest behavior, corruption, and Brazilian jeitinho. She is a member of the Laboratory of Social Psychology (LAPSOCIAL) and the Group of Research in Social Psychology (GEPS).

ORCID: https://orcid.org/0000-0001-5158-8770

E-mail: jessicaemfarias@hotmail.com

Ronaldo Pilati is doctor in Psychology at University of Brasília (UnB). He is an associate professor in the Department of Social and Work Psychology and in the Program of Social, Work and Organizational Psychology at UnB. He was an associate editor and editor in chief of the journal Psicologia Teoria e Pesquisa (Psychology Theory and Research) between 2008 and 2013. He was director of the Brazilian Society of Psychology (SBP) for two mandates: 2014-2015 and 2016-2017. He was an elected member of SBP Council in the mandate 2018-2019. He is president during the mandate 2020-2021. He is the author of the book "Science and Pseudoscience: Why we believe only what we want to believe".

ORCID: https://orcid.org/0000-0003-2982-5033

E-mail: rpilati@unb.br

Contato com os autores:

Jéssica Farias

E-mail: jessicaemfarias@hotmail.com

Ronaldo Pilati

E-mail: rpilati@unb.br 